\title{
Blocking TNF- $\alpha$ in Complex Regional Pain Syndrome Type I: A Case of Reflex Sympathetic Dystrophy Resolved with Etanercept in a Patient with Ankylosing Spondylitis
}

\author{
Kompleks Bölgesel Ağrı Sendromu Tip I'de TNF-a Blokaj: \\ Ankilozan Spondilitli Bir Hastada Gelişen ve Etanersept ile İyileşen Bir \\ Refleks Sempatik Distrofi Olgusu
}

Ahmet ÖZGÜL, Dilek VURAL, Mehmet Ali TAŞKAYNATAN

Department of Physical Medicine and Rehabilitation, Gülhane Military Medical Academy, TAF Rehabilitation Center, Ankara, Turkey

Complex regional pain syndrome type I (CRPS1) is a painful clinical condition that may develop mostly as a result of trauma affecting the limbs. Hyperalgesia, allodynia, spontaneous pain, and autonomic disturbances along with swelling and impairment of motor functions are the hallmarks. Ultimately, this syndrome may lead to disability. Although many different kinds of treatments have been tried, the success of these treatments has been limited. Inflammatory signs appear especially in the early and mid-stages of the disease. These findings may favor the use of new treatment modalities including the use of new generation medicines like monoclonal antibodies in the treatment of CRPS. In this article, we report the complete resolution of CRPS1 with the TNF- $\alpha$-blocker etanercept in a 62-year-old female patient with ankylosing spondylitis.

Key words: Anti-TNF-alfa; reflex sympathetic dystrophy; complex regional pain syndrome type 1 .

Complex regional pain syndrome type I (CRPS1), also known as reflex sympathetic dystrophy syndrome (RSD), represents a painful clinical condition in which hyperalgesia, spontaneous pain, allodynia, and autonomic disturbances along with swelling and impairment of motor functions are major findings. These abnormalities are disproportionate to the inciting event and are not limited to a single peripheral
Kompleks bölgesel ağrı sendromu tip I (KBAS1), çoğunlukla ekstremiteleri etkileyen travma sonucu gelişen ağrılı bir klinik durumdur. Hiperaljezi, allodini, spontan ağrı ve otonomik bozukluklar beraberliğinde şişlik ve motor fonksiyon bozuklukları hastalığa özgü bulgulardır. Bu sendrom sonunda engellilik durumuna yol açabilir. Çok farklı tedaviler denenmiş olmakla birlikte bu tedavilerin başarısı sınırlı kalmıştır. Hastalığın özellikle erken ve orta dönemlerinde inflamatuvar bulgular ortaya çıkmaktadır. Bu bulgular KBAS tedavisinde monoklonal antikorlar gibi yeni kuşak ilaçların kullanımını içeren yeni tedavi yöntemlerinin öne çıkmasına yol açabilecektir. Bu makalede ankilozan spondlitli 62 yaşında bir kadın hastada gelişen KBAS1'in TNF- $\alpha$ blokörü etanersept ile tamamen iyileşmesi bildirilmiştir.

Anahtar sözcükler: Anti-TNF-alfa; refleks sempatik distrofi; kompleks bölgesel ağrı sendromu tip 1 .

nerve territory. ${ }^{[1,2]}$ If the involved extremity is not mobilized adequately, limb atrophy and contractures may occur. Patients usually suffer from intense pain, and they show different pain behaviors that may affect daily life. Its treatment is still a dilemma, and there is no universally accepted treatment strategy. Although very different kinds of treatments have been tried, none has given satisfactory results, ${ }^{[3]}$ probably as a result

Received: October 10, 2009 Accepted: September 10, 2010

Correspondence: Ahmet Özgül, M.D. Gülhane Askeri Tıp Akademisi, Fiziksel Tıp ve Rehabilitasyon Anabilim Dalı, TSK Rehabilitasyon Merkezi, 06540 Bilkent, Ankara, Turkey. Tel: +90 312 - 2911700 e-mail: ahmet@ahmetozgul.com

(c)2011 Turkish League Against Rheumatism. All rights reserved. 
of an insufficient understanding of the pathogenesis. Theories regarding the pathogenesis include irritation and abnormal excitation of the nerve tissue which may lead to abnormal impulses along nerves. These changes affect the blood vessels and skin. However, no single theory can explain all features of the CRPS. Some recent studies have emphasized the inflammatory activity in earlier stages of the disease. ${ }^{[4,5]}$

Here, we report resolution of CRPS1 in a patient, who already had a diagnosis of ankylosing spondylitis (AS), with the treatment of the tumor necrosis factor (TNF)-blocker etanercept.

\section{CASE REPORT}

A 62-year-old female patient who was undergoing follow-up for AS reported that she had fallen five months ago due to an ankle distortion. Her diagnosis of AS was made a few years ago. Her right ankle became swollen and painful a few days after the fall. The patient received treatment for one month and then underwent parenteral antibiotherapy for ten days in an inpatient orthopedic clinic. Because there was no improvement, she underwent an arthroscopic synovectomy and cartilage debridement; however, her complaints did not resolve.

The patient was referred to our clinic for her ongoing painful, swollen ankle and foot complaint. She was not able to walk without an aid or perform daily activities due to pain. Upon physical examination, she had swelling, warmth, and profound tenderness in the right ankle and foot. She had also redness, hypersensitivity, and shiny skin on her right foot. Her right ankle could not be palpated due to allodynia and hyperalgesia, and her right ankle motions were more than $50 \%$ restricted compared to the normal range. The nails on the right side grew less than the left, and there was piloerection on the affected side. She had spontaneous pain of $7 / 10$ on the visual analog scale (VAS) and 9/10 with palpation.

The patient had already been diagnosed with AS according to the modified New York criteria. She had bilateral sacroiliitis, lumbar motion restriction, morning stiffness, and enthesitis. Laboratory examination showed a high erythrocyte sedimentation rate (ESR) $(65 \mathrm{~mm} / \mathrm{h})$ and C-reactive protein (CRP) $(20 \mathrm{mg} / \mathrm{dl})$ along with a Bath Ankylosing Spondylitis Disease Activity Index (BASDAI) of 5.1. Her earlier magnetic resonance imaging (MRI) and bone scanning were compatible with sacroiliitis and enthesopathies. Therefore, we looked for an AS-related pathology. She had bilateral ankle synovitis in ultrasonography, but an MRI revealed little synovitis and/or tenosynovitis in the right ankle. It showed periarticular and periosseous edema. An X-ray showed one-sided diffuse osteoporosis (figure 1a). Three-phase bone scanning showed diffuse increased uptake on delayed phase in the right foot which is consistent with CRPS1. Her clinical picture met the criteria for CRPS1 according to the Kozin criteria. ${ }^{[6]}$ Otherwise, her general clinical picture was compatible with active AS.

A treatment of intense physical therapy and rehabilitation along with semi-synthetic opioids provided some relief from the symptoms. On the other hand, the inflammatory condition related to AS didn't show any improvement despite long-term methotrexate treatment and systemic steroids as well as non-steroid anti-inflammatory medications. We decided to start a TNF- $\alpha$ blocker treatment (etanercept, $25 \mathrm{mg}$ two times a week subcutaneously). One month later, the patient had a walking distance of $200 \mathrm{~m}$ with moderately less pain. She had no spontaneous or evoked pain. Although her dermis was still shiny, there was no color change or warmth. Her nails were growing equally on both sides.

Three weeks later, the patient was able to walk more than five minutes without pain. Her dermis was nearly normal, and she had no pain. She was able to perform her daily activities freely and felt much better with the decrease in inflammatory activity of AS. Acute phase reactants had returned to normal ranges. Her sleeping quality had increased, and her morning stiffness had decreased significantly. A bone scan showed no pathology. A control X-Ray did not show the diffuse osteoporosis (figure $1 \mathrm{~b}$ ).
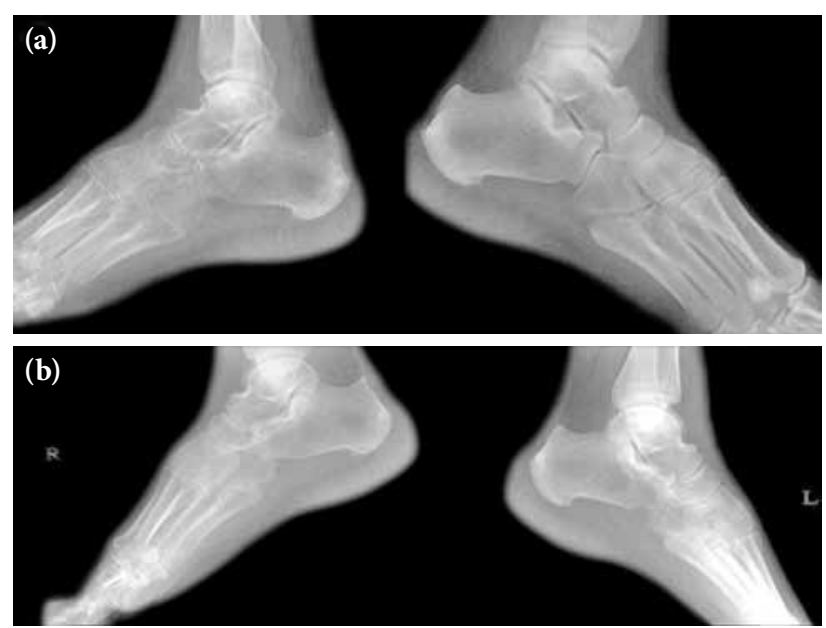

Figure 1. (a) The X-ray image of the feet before (b) and five months later. 


\section{DISCUSSION}

Complex regional pain syndrome type I is a syndrome of spontaneous pain with vasomotor and sudomotor changes. These symptoms are disproportionate to the inciting event and are not related to a single nerve territory. As the cause of CRPS1 is still controversial, different mechanisms have been postulated in the pathophysiology. However, these mechanisms cannot explain the entire problem. A local circuit of neural and vascular disturbances or an inflammatory process may be responsible.

Various treatments have been used to alleviate the problem. ${ }^{[7-10]}$ Physical medicine and rehabilitation (PM\&R) modalities combined with other treatments offer fairly good success, especially in early cases. ${ }^{[1]}$ PM\&R modalities, such as pain-alleviating electrical currents, anti-edema massage and exercise along with different kinds of medicines including corticosteroids, $\beta-2$ blockers, semi-synthetic opioids, and non-steroidal anti-inflammatory drugs, are the most widely used treatment options in CRPS. However, these treatment options, either given singularly or in combination, do not usually provide satisfactory success.

Inflammatory processes are known to be involved in the early and intermediate phases of CRPS1. ${ }^{[12]}$ Some researchers have shown that the pro-inflammatory cytokines interleukin (IL)- 6 and TNF- $\alpha$ increased while the anti-inflammatory cytokines decreased in the earlier phases of CRPS1. ${ }^{[5,13,14]}$ Nowadays, the biologics, including monoclonal antibodies, are drawing more attention in CRPS. ${ }^{[15]}$

Theories related to pathogenesis encompass plasticity both at the dorsal root ganglion (DRG) and spinal levels. Animal studies have shown an increase of TNF at these regions after a nerve injury. ${ }^{[16,17]}$ TNF- $\alpha$ may lead to increased p38, which is a factor involved in the generation of pain behavior. Ultimately, a cycle that activates DRG by TNF- $\alpha$ and p38, interleukins, or cyclooxygenase may ensue. TNF- $\alpha$ can induce ectopic activity in primary afferent nociceptors, and thus is a potential cause of pain and hyperalgesia in CRPS1. ${ }^{[14,18,19]}$

On the other hand, local organic disturbances may provide other causes of the pain. Osteoporosis (OP) and soft tissue degeneration may be the cause of ultimate signs and symptoms. The effect of protective or pain-related immobilization on these disturbances is not understood. TNF- $\alpha$ can be locally synthesized and released by osteoblasts and mononuclear cells.
It has been shown that substance P (SP) induces the release of IL-1 and TNF- $a \cdot{ }^{[20]}$ In this context, SP may cause CRPS1 symptoms by activating local vascular and neural disturbances, or it can have an indirect role induced by these events. The release of nitric oxide (NO) driven by IL-1 and TNF- $\alpha$ in inflammation is another cause of OP, which perhaps is also true for localized inflammatory or non-inflammatory lesions. A study by Redlich et al. ${ }^{[21]}$ showed that bone destruction in inflammatory arthritis is driven by osteoclasts in which TNF- $\alpha$ plays an important role. TNF- $\alpha$ may be important in the pathogenesis, and the inciting process may be driven particularly by this cytokine. In accordance with this suggestion, Wagner et al. ${ }^{[22]}$ showed decreased levels of TNF- $\alpha$ after administration of the anti-inflammatory cytokine IL-10.

The use of anti-TNF blockers, in this case etanercept, may take part in all these mechanisms by previously proposed actions. The efficacy of TNF- $\alpha$ blockers given by systemic or local intravenous routes has been shown. ${ }^{[23]}$ Although it reverses the whole inflammatory response in chronic inflammatory diseases, pain reduction may not only be related only to decreased synovitis, but it may also be induced by the aforementioned neural pathways.

The hyperalgesia and allodynia are possibly due to bone and soft tissue changes in relation to the pain transmission pathways or neural plasticity in the central nervous system. TNF-blockers may directly or indirectly affect both routes of symptoms in CRPS1. It is known that anti-TNF medications may be used to prevent or reverse systemic bone loss associated with inflammatory disease.

In our case, a doubt about the CRPS1 diagnosis might be raised because of the possibility of arthritis. However, consultations with radiologists and nuclear medicine specialists in conjunction with the clinical and radiological findings compatible with IASP (International Association for the Study of Pain) criteria made the diagnosis adequately certain.

In conclusion, we think that anti-TNF- $\alpha$ drugs may be a potential treatment option in CRPS. TNF- $\alpha$ may be responsible from the primary pathology in CRPS which involves the neurovascular and osseous components. Blocking TNF- $\alpha$ would be effective in inflammatory pathways and, as a result, it would lead to stopping the pain circuit. Once the painful osteoporosis is prevented, the patient may use the extremity better in daily life. In such pathologies, unless the patient cannot tolerate it, exercise and weight bearing are very important in the 
treatment. Obtaining good circulation and alleviating the pain would help the patients to use the affected part comfortably. Consequently, the osteoporosis would disappear significantly. To explore the exact effect of the mechanisms of this medication on CRPS, further investigations and randomized controlled studies are needed.

\section{Declaration of conflicting interests}

The authors declared no conflicts of interest with respect to the authorship and/or publication of this article.

\section{Funding}

The authors received no financial support for the research and/or authorship of this article.

\section{REFERENCES}

1. Merskey H, Bogduk N. Complex regional pain syndrome (CRPS), a relatively generalized syndrome. Part II, Detailled descriptions of pain syndromes. In: Merskey H, Bogduk N, editors. Classification of chronic pain. 2nd ed. Seattle: IASP Press; 1994. p. 40-3.

2. Perez RS, Kwakkel G, Zuurmond WW, de Lange JJ. Treatment of reflex sympathetic dystrophy (CRPS type 1): a research synthesis of 21 randomized clinical trials. J Pain Symptom Manage 2001;21:511-26.

3. Reuben SS, Sklar J. Intravenous regional anesthesia with clonidine in the management of complex regional pain syndrome of the knee. J Clin Anesth 2002;14:87-91.

4. Huygen FJ, De Bruijn AG, De Bruin MT, Groeneweg JG, Klein J, Zijlstra FJ. Evidence for local inflammation in complex regional pain syndrome type 1. Mediators Inflamm 2002;11:47-51.

5. Uçeyler N, Eberle T, Rolke R, Birklein F, Sommer C. Differential expression patterns of cytokines in complex regional pain syndrome. Pain 2007;132:195-205.

6. Kozin F. Reflex sympathetic dystrophy syndrome. Curr Opin Rheumatol 1994;6:210-6.

7. Zuurmond WW, Langendijk PN, Bezemer PD, Brink HE, de Lange JJ, van loenen AC. Treatment of acute reflex sympathetic dystrophy with DMSO $50 \%$ in a fatty cream. Acta Anaesthesiol Scand 1996;40:364-7.

8. Jadad AR, Carroll D, Glynn CJ, McQuay HJ. Intravenous regional sympathetic blockade for pain relief in reflex sympathetic dystrophy: a systematic review and a randomized, double-blind crossover study. J Pain Symptom Manage 1995;10:13-20.

9. Kemler MA, Barendse GA, van Kleef M, de Vet HC, Rijks CP, Furnée CA, et al. Spinal cord stimulation in patients with chronic reflex sympathetic dystrophy. $\mathrm{N}$ Engl J Med 2000;343:618-24.
10. Taskaynatan MA, Ozgul A, Tan AK, Dincer K, Kalyon TA. Bier block with methylprednisolone and lidocaine in CRPS type I: a randomized, double-blinded, placebocontrolled study. Reg Anesth Pain Med 2004;29:408-12.

11. Oerlemans HM, Oostendorp RA, de Boo T, Goris RJ. Pain and reduced mobility in complex regional pain syndrome I: outcome of a prospective randomised controlled clinical trial of adjuvant physical therapy versus occupational therapy. Pain 1999;83:77-83.

12. Wesseldijk F, Huygen FJ, Heijmans-Antonissen C, Niehof SP, Zijlstra FJ. Tumor necrosis factor-alpha and interleukin- 6 are not correlated with the characteristics of Complex Regional Pain Syndrome type 1 in 66 patients. Eur J Pain 2008;12:716-21.

13. Drummond PD. Mechanism of complex regional pain syndrome: no longer excessive sympathetic outflow? Lancet 2001;358:168-70.

14. Huygen FJ, de Bruijn AG, Klein J, Zijlstra FJ. Neuroimmune alterations in the complex regional pain syndrome. Eur J Pharmacol 2001;429:101-13.

15. Huygen FJ, Niehof S, Zijlstra FJ, van Hagen PM, van Daele PL. Successful treatment of CRPS 1 with antiTNF. J Pain Symptom Manage 2004;27:101-3.

16. Hashizume H, DeLeo JA, Colburn RW, Weinstein JN. Spinal glial activation and cytokine expression after lumbar root injury in the rat. Spine 2000;25:1206-17.

17. Schäfers M, Svensson CI, Sommer C, Sorkin LS. Tumor necrosis factor-alpha induces mechanical allodynia after spinal nerve ligation by activation of p38 MAPK in primary sensory neurons. J Neurosci 2003;23:2517-21.

18. Sorkin LS, Xiao WH, Wagner R, Myers RR. Tumour necrosis factor-alpha induces ectopic activity in nociceptive primary afferent fibres. Neuroscience 1997;81:255-62.

19. Sommer C, Schmidt C, George A. Hyperalgesia in experimental neuropathy is dependent on the TNF receptor 1. Exp Neurol 1998;151:138-42.

20. Branchet-Gumila MC, Boisnic S, Le Charpentier Y, NonotteI,MontastierC,BretonL.Neurogenicmodifications induced by substance $\mathrm{P}$ in an organ culture of human skin. Skin Pharmacol Appl Skin Physiol 1999;12:211-20.

21. Redlich K, Hayer S, Ricci R, David JP, TohidastAkrad M, Kollias G, et al. Osteoclasts are essential for TNF-alpha-mediated joint destruction. J Clin Invest 2002;110:1419-27.

22. Wagner R, Janjigian M, Myers RR. Anti-inflammatory interleukin-10 therapy in CCI neuropathy decreases thermal hyperalgesia, macrophage recruitment, and endoneurial TNF-alpha expression. Pain 1998;74:35-42.

23. Bernateck M, Rolke R, Birklein F, Treede RD, Fink M, Karst M. Successful intravenous regional block with lowdose tumor necrosis factor-alpha antibody infliximab for treatment of complex regional pain syndrome 1 . Anesth Analg 2007;105:1148-51. 